\title{
DIGITAL HYPOPERFUSION ISCHEMIC SYNDROME IN THE PATIENTS WITH TRANSPOSITION OF THE BASILIC VEIN
}

\section{AUTHORS}

Stolic R. ${ }^{1}$, Milinic S. ${ }^{2}$, Sipic M. ${ }^{2}$, Odalovic B. ${ }^{2}$, Odalovic D. ${ }^{2}$

${ }_{1}^{1}$ University of Kragujevac, Faculty of Medicine, Kragujevac, Clinic of nephrology, Serbia

${ }^{2}$ University of Pristina, Faculty of Medicine Pristina/K.Mitrovica

\section{SUMMARY}

Transposition veins, in some cases when there is no adequate superficial veins, preferred is model of the vascular access. This approach may be acceptable version vascular access where is not possible to create other shapes. But basilic vein transposition is time consuming and technically challenging procedure with significant perioperative morbidity. Complication rate for basilic vein transposition remains high at $47-71 \%$. We report a patient who underwent transposition basilic vein, and its anastomosis with radial artery, in which developed the digital hypoperfusion ischemic syndrome.

Keywords: Vascular access, Transposition, Basilic vein, Hemodialysis

\section{INTRODUCTION}

Transposition veins, in some cases when there is no adequate superficial veins, preferred is model of the vascular access. This approach may be acceptable version vascular access where is not possible to create other shapes. But basilic vein transposition is time consuming and technically challenging procedure with significant perioperative morbidity. Complication rate for basilic vein transposition remains high at $47-71 \%$ [1]. We report a patient who underwent transposition basilic vein, and its anastomosis with radial artery, in which developed the digital hypoperfusion ischemic syndrome.

\section{CASE REPORT}

We report a patient who underwent transposition basilic vein, and its anastomosis with radial artery, in which developed the digital hypoperfusion ischemic syndrome. Patient AM, a 55-year-old man, was hospitalized in the Center of Nephrology and Dialysis, Kragujevac Clinical Center, Serbia due to multiple thromboses of arteriovenous fistulae for hemodialysis.

Inspection of the right forearm we are not differentiate vein which has a good lumen in the near of the radial artery. Therefore, we decided to do the transposition of basilic vein and anastomose with the radial artery. Before surgery we are phlebography determined location and topography (Figure 1) determining its morphological features, functionality and mobility. During surgical interventions basilic veins are anatomically lo- cate and after checking its potency (Figure 2), successful anastomoses with the radial artery.

Figure 1. Multiple fistula thrombosis, marking of incisions and phlebography of the right basilic vein

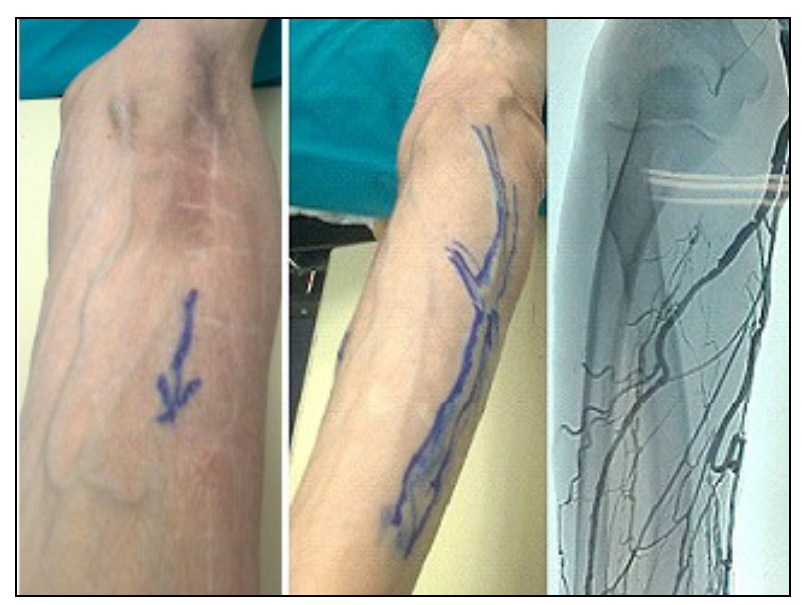

\section{DISCUSION}

The basilic vein is long, with a relatively large diameter. Venous flow is fast with high patency. It matures early and provides a longer conduit for dialysis. However basilic vein transposition is a time consuming and technically challenging procedure with significant perioperative morbidity [2]. According to some authors the functionality of this approach is $75 \%$ over 8 years [3] or $76.7 \%$ dur- 
ing one and $49.2 \%$ over 4 years [4]. A review of the literature we could not find works that show the emergence of digital hypoperfusion after creating vascular access by method of transposition basilic vein. Nevertheless, the reported complication rate for basilic vein transposition remains high at $47-71 \%$ [5].

Figure 2. Transposition basilic vein in the forearm area vein and checking of the flexibility walls

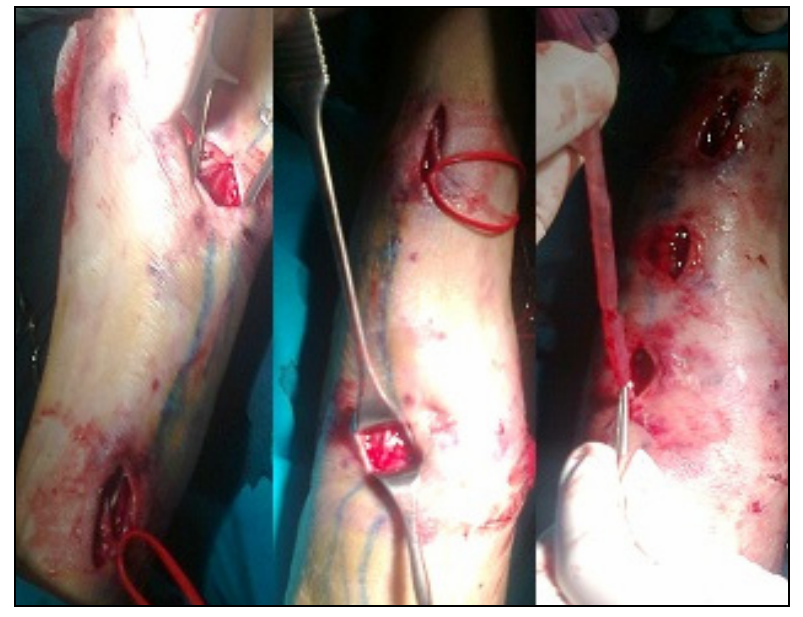

Unfortunately, in the our case report, eight months after transposition, the basilic vein developed digital hypoperfusion ischemic syndrome with elements of cellulitis (Figure 3), and shortly thereafter thrombosis occurred.

Our experience with creation of arteriovenous fistulas for hemodialysis by transposition of veins, shows that there are still are many dilemmas and complications, which should be taken into consideration before deciding on this type of vascular access $[6,7,8]$.
Figure 3. Digital hypoperfusion ischemic syndrome and cellulitis in the patients with transposition of the basilic vein

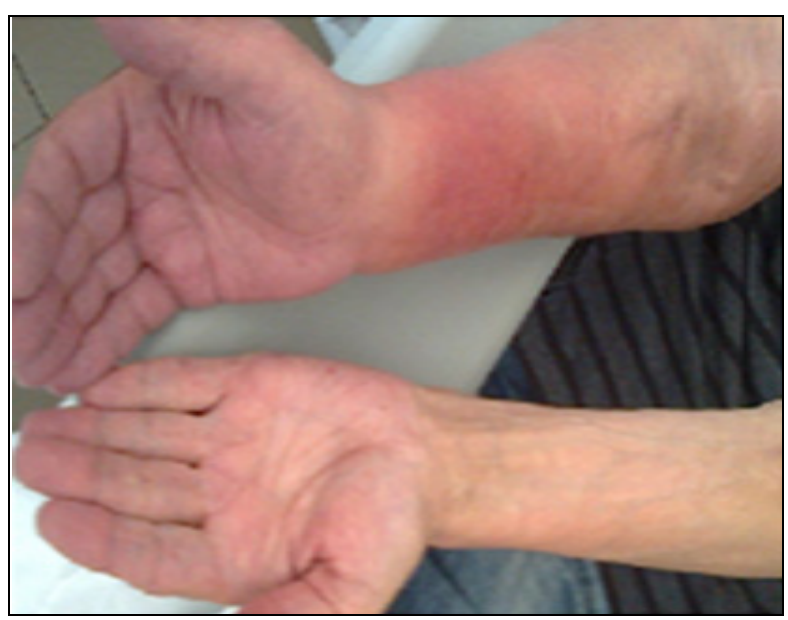

\section{CONCLUSION}

We presented arteriovenous fistula, the transposition of basilic vein and its anastomosis with radial artery, but, as an epilogue with the final thrombosis, after clinical diagnosis of the distal ischemia with elements of cellulitis.

\section{REFERENCES}

1. Tordoir JHM, Dammers R, de Brauw M. Video-assisted basilic vein transposition for haemodialysis vascular access: preliminary experience with a new technique. Nephrol Dial Transplant 2001;16: 391-94.

2. Taghizadeh A, Dasgupta P, Khan MS. Long-term outcomes of brachiobasilic transposition fistula for haemodialysis. Eur J Vasc Endovasc Surg 2003; 26: 670-672.

3. Coburn MC, Carney WI Jr. Comparison of basilic vein and polytetrafluroethylene for brachial arteriovenous fistula. Vasc Surg 1994; 20: 896-902.

4. Elcheroth J, de Pauw L, Kinnaert DP. Elbow arteriovenous fistulas for chronic haemodialysis. British Journal of Surgery 1994; 81: 982-984.

5. Veeramani M, Vyas J, Sabnis R, Desai M. Small incision basilic vein transposition technique: A good alternative to standard method. Indian J Urol 2010; 26: 145-147.

6. Stolic RV, Trajkovic GZ, Miric DJ, Kisic B, Djordjevic Z, Azanjac GLj, et al. Arteriovenous fistulas and digital hypoperfusion ischemic syndrome in patients on hemodialysis. World J Nephrol 2013; 6: 26-30.

7. Stolic R, Mijailovic M, Cvetkovic A, Stanojevic M, Stolic Dz, Cvetkovic D. Distal ischemia induced by vascular access for hemodialysis - a case report. Hippokratia 2012; 16: 375-377.

8. Stolic R. Most important chronic complications of arteriovenous fistulas for hemodialysis. Med Princ Pract 2013; 22: 220-228. 


\section{CASE REPORTS}

\section{SRPSKI}

\section{DIGITALNI HIPOPERFUZIONI ISHEMIJSKI SINDROM KOD PACIJENTA SA TRANSPOZICIJOM BAZILICNE VENE}

Stolic R. ${ }^{1}$, Milinic S. ${ }^{2}$, Sipic $M .^{2}$, Odalovic B. ${ }^{2}$, Odalovic D. ${ }^{2}$

${ }^{1}$ Univerzitet u Kragujevcu, Fakultet medicinskih nauka, Klinika za nefrologiju, Srbija

${ }^{2}$ Univerzitet u Pristini, Medicinski fakultet, Pristina - Kosovska Mitrovica

\section{SAŽETAK}

Onda kada nema adekvatne vene, transpozicija dubokih vena i njihova anastomoza sa bliskom arterijom može pretstavljati poželjan model vaskularnog pristupa. Ovo rešenje je prihvatljiv oblik kada nije moguće drugačije rešenje. Međutim, transpozicvija vene je dugotrajan i tehnički zahtevan postupak koji dovodi do značajnih postoperativnih komplikacija u 47-71\% slučajeva. Prikazujemo bolesnika kojem smo kreirali vaskularni pristup za hemodijalizu transpozicijom bazilične vene i njenu enastomozu sa radijalnom arterijom, kod kojeg se razvila digitalna hipoperfuzija sa ishemijskim sindromom.

Ključne reči: Vaskularni pristup, Transpozicija, Bazilična vena, Hemodijaliza 